\title{
Phytoremediation: A Plant - Based Technology
}

\author{
Mansoor Ali ${ }^{*}$, A.K. Bhat, Tsering Dolkar and M.A. Malik \\ Department of Soil Science, Sher-e-Kashmir University of Agriculture Science and \\ Technology Shalimar, India \\ *Corresponding author
}

\begin{tabular}{|c|c|}
\hline & I R \\
\hline & \multirow{6}{*}{$\begin{array}{l}\text { Heavy metal contamination has increased rapidly since the early } 20^{\text {th }} \text { century. A Large part } \\
\text { of the world has been contaminated by organic and inorganic pollutants. Phytoremediation } \\
\text { involves the use of plants to remove, transfer, stabilize and/or degrade contaminants in } \\
\text { soil, sediment, and water. This plant-based technology has gained acceptance in the past } \\
\text { ten years as a cheap, efficient and environmentally friendly technology especially for } \\
\text { removing toxic metals. Currently, 6-8 billion US dollars are spent annually for } \\
\text { environmental cleanup alone in the United States and worldwide it is } 25-50 \text { billion US } \\
\text { dollars per year. Sebera acuminate and Thlaspi caerulescens (Cunningham and Ow 1996), } \\
\text { Arabidopsis thaliana (Delhaize 1996), Typha latifolia, and Phragmites australis (Ye et al., } \\
\text { 2001) are some identified plants which are known for heavy metals accumulation in their } \\
\text { tissues. In zinc and lead mine's Typha latifolia and Phragmites australis have been } \\
\text { successfully used for phytoremediation in China. Water hyacinth (Eichhornia crassipes, } \\
\text { Kay et al., 1984; Zhu et al., 1999), pennywort (Hydrocotyle umbellata L., Dierberg et al., } \\
\text { 1987), and duckweed (Lemna minor L., Mo et al., 1989) are some important aquatic } \\
\text { species known for the remediation of aquatic ecosystem. Further explorations are needed } \\
\text { in the field of Phytoremediation to address technical issues and to find out the } \\
\text { geographically suitable plant species for effective phytoremediation. Accumulation of } \\
\text { heavy metals by plants is affected by many factors, variations in plant species, plants } \\
\text { growth stage and element characteristics control absorption, accumulation and } \\
\text { translocation of metals. }\end{array}$} \\
\hline Keywords & \\
\hline & \\
\hline $\mathbf{A r}$ & \\
\hline & \\
\hline & \\
\hline
\end{tabular}

\section{Introduction}

Heavy metals constitute a heterogenous group of elements; a relatively high density of approximately $6 \mathrm{~g} \mathrm{~cm}^{-3}$ is their common characteristic with atomic weight more than that of iron (Alloway, 1997). Heavy metal contamination has increased rapidly since the early $20^{\text {th }}$ century (Nriagu, 1979; Ensley, 2000). A Large part of the world has been contaminated by organic and inorganic pollutants. Organic pollutants are mainly spread through anthropogenic activities and are released into the environment through industrial activities, agricultural practices, military operations and fuel spills. Some organic pollutants such as trichloroethane (TCE) known as common ground water pollutant (Newman et al., 1997), atrazine used as herbicides (Burken and Schnoor, 1997), 
trinitrotoluene (TNT) used as an explosive material (Hughes et al., 1997), hydrocarbons such as oil, gasoline, benzene, toluene, and polycyclic aromatic hydrocarbons (PAHs) (Schnoor et al., 1995, Aprill and Sims, 1990), fuel additives such as methyl tertiary butylether (MTBE) (Hong et al., 2001) and polychlorinated biphenyls (PCBs) (Harms et al., 2003). Plant macronutrients such as nitrates and phosphates, micronutrients such as $\mathrm{Cr}, \mathrm{Cu}, \mathrm{Fe}, \mathrm{Mn}, \mathrm{Mo}, \mathrm{Ni}$ and $\mathrm{Zn}$, nonessential elements such as $\mathrm{As}, \mathrm{Cd}, \mathrm{Co}, \mathrm{F}$, $\mathrm{Hg}, \mathrm{Se}, \mathrm{Pb}, \mathrm{V}$, and $\mathrm{W}$, and radionuclides such as ${ }^{238} \mathrm{U},{ }^{137} \mathrm{Cs}$, and ${ }^{90} \mathrm{Sr}$ are commonly known as inorganic pollutants (Dushenkov, 2003). Sources of heavy metal contaminants in soils include metalliferous mining and smelting, metallurgical industries, sewage sludge treatment, warfare and military training, waste disposal sites, agricultural fertilizers and electronic industries (Alloway, 1995). Toxic heavy metals cause DNA damage, and their carcinogenic effects in animals and humans are probably caused by their mutagenic ability (Knasmuller et al., 1998; Baudouin et al., 2002). Metal-contaminated soil can be remediated by chemical, physical or biological techniques (McEldowney et al., 1993). Chemical and physical treatments irreversibly affect soil properties, destroy biodiversity and may render the soil useless as a medium for plant growth. While as biological techniques include the phytoremediation has proved to be very efficient and environmentally friendly technique. The cost involved in the cleanup of heavy metal contaminated sites is huge not only for the developing nations but also for the developed countries like the United States. Currently, 6-8 billion US dollars are spent annually for environmental cleanup alone in the United States and worldwide it is 25-50 billion US dollars per year (Tsao, 2003). Bioremediation is another microbe-based technology along with the phytoremediation plant-based technology can be used for the cost-effective remediation of the contaminated sites (Pilon-Smits, 2005). Because of its low cost technology phytoremedation can become a very useful technology for the developing nations like India where there is shortage of funds for the environmental cleanups. Phytoremedation can also become an income generating technology by extracting some useful metals from the plants which are used to remove the metals from the soil particularly known as the phytomining (Brooks et al., 1998; Angle et al., 2001). Numerous research are currently carried out to find out the potential of these technology (Ghosh and Singh, 2005) with several plants are identified suitable for the phytoremediation and phytomining of $\mathrm{Ni}, \mathrm{Co}, \mathrm{Tl}, \mathrm{Pb}, \mathrm{Cu}, \mathrm{Zn}$ (Anderson et al., 1999; Chaney et al., 1997; Brooks et al., 2001; Boominathan et al., 2004).

\section{Plants for Phytoremediation}

Phytoremediation involves the use of plants to remove, transfer, stabilize and/or degrade contaminants in soil, sediment, and water (Hughes et al., 1997). This plant-based technology has gained acceptance in the past ten years as a cheap, efficient and environmentally friendly technology especially for removing toxic metals. Phytoremediation is the ability of plants to concentrate elements and compounds from the contaminated soils and water bodies and to metabolize molecules in their tissues appears very promising method for removal of pollutants from the soil and water (Gurbisu and Alkorta, 2003). Plant roots are mostly located in the soil, they can play a very crucial role in metal removal via filtration, adsorption and cation exchange, and chemical changes that takes place in the rhizosphere through plant roots (Dunbabin and Bowmer, 1992; Wright and Otte, 1999). Sebera acuminate and Thlaspi caerulescens (Cunningham and Ow, 1996), Arabidopsis thaliana (Delhaize, 1996), Typha latifolia, and Phragmites australis (Ye 
et al., 2001) are some identified plants which are known for heavy metals accumulation in their tissues. In zinc and lead mine's Typha latifolia and Phragmites australis have been successfully used for phytoremediation in China (Ye et al., 1997a, b). Water hyacinth (Eichhornia crassipes, Kay et al., 1984; Zhu et al., 1999), pennywort (Hydrocotyle umbellata L., Dierberg et al., 1987), and duckweed (Lemna minor L., Mo et al., 1989) are some important aquatic species known for the remediation of aquatic ecosystem. However, because of their small and slow growing roots, these plants have limited potential for rhizofiltration (Dushenkov et al., 1995). The two most promising terrestrial species for removing metals from water are Sunflower (Helianthus annus L.) and Indian mustard (Brassica juncea Czern.). Dushenkov et al., (1995) reported that Indian mustard is effective in accumulating $\mathrm{Cd}, \mathrm{Cr}, \mathrm{Cu}, \mathrm{Ni}, \mathrm{Pb}$, and $\mathrm{Zn}$, whereas sunflower efficiently removes $\mathrm{Pb}$ (Dushenkov et al., 1995), U (Dushenkov et al., 1997a), ${ }^{137} \mathrm{Cs}$, and ${ }^{90} \mathrm{Sr}$ (Dushenkov et al., 1997b) from hydroponic solutions. A glasshouse investigation was undertaken to evaluate the natural potential of fenugreek (Trigonella foenumgraecum L.), spinach (Spinacia oleracea L.), and raya (Brassica campestris L.) for cleanup of chromium $(\mathrm{Cr})$-contaminated silty loam and sandy soils. Figure 1 and 2 summarized the $\mathrm{Cr}$ uptake in fenugreek, spinach, and raya increased with increasing level of added $\mathrm{Cr}$ in both soils. The findings indicated that family Cruciferae (Raya) was most tolerant to $\mathrm{Cr}$ toxicity, followed by chenopodiacea (spinach) and Leguminosae (fenugreek). Because raya removed the highest amount of $\mathrm{Cr}$ from the soil, it could be used for phytoremediation of mildly Cr-contaminated soils (Dheri et al., 2007).

A comparative study was carried out in order to find $\mathrm{Cr}$ extraction in five different weeds and two Brassica species was in ascending order: Ipomeia. Carnea, Dhatura innoxia,
Cassia tora, Phragmytes karka, Brassica juncea, Lantana camara and Brassica campestris respectively (Ghosh and Singh, 2005). Among the all Phragmytes karka showed much greater tolerance to metals but the uptake was less as compared to other plants. Other than Lantana camara, all the tested weeds were better for chromium extraction than the accumulator Brassica species. This indicates that weeds can be used in place of brassica species and it requires very less cure (Fig. 3). Deepali and Gangwar (2009) found in their study that the $\mathrm{Cr}$ accumulation in the roots and shoots of Spinacea olaracea in percent are shown in Figure 4 were higher at minimum concentration.

Hyperaccumulators are that of special category of plants that can accumulate extraordinary levels of metals, the idea of using these plants for phytoextraction only appeared in the literature in the $\mathrm{Zn}$ up to levels that are 100 to 1,000 times of those normally accumulated by plants grown under the same conditions (Baker et al., 2000; Ma et al., 2001; Brooks, 1998). A number of these species are members of Brassicaceae, including a species of Arabidopsis, A. halleri, which can hyper accumulate $\mathrm{Zn}$ in its shoots (Reeves and Backer, 2000). Recently, Sonchus asper and Corydalis pterygopetata grown on lead - zinc mining area in China have been identified as heavy metal hyperaccumulators (Yanqun et al., 2005). A list of 775 plant species database (PHYTOREM) has been developed by Environment Canada with capabilities to accumulate or hyperaccumulate one or several key metallic elements. So far only one hyperaccumulator species, the $\mathrm{Ni}$ hyperaccumulator. Alyssum bertolonii, has been used for phytoremediation in the field (Chaney et al., 2000; Li et al., 2003). Pteris vittata, an Arsenic (As) hyperaccumulating fern may also show promise for phytoextraction of As. 
Fig.1 Chromium uptake in shoots of different crops grown in two $\mathrm{Cr}$ contaminated soils (soil 1 texture- silty loam and soil 2 - sandy soils)

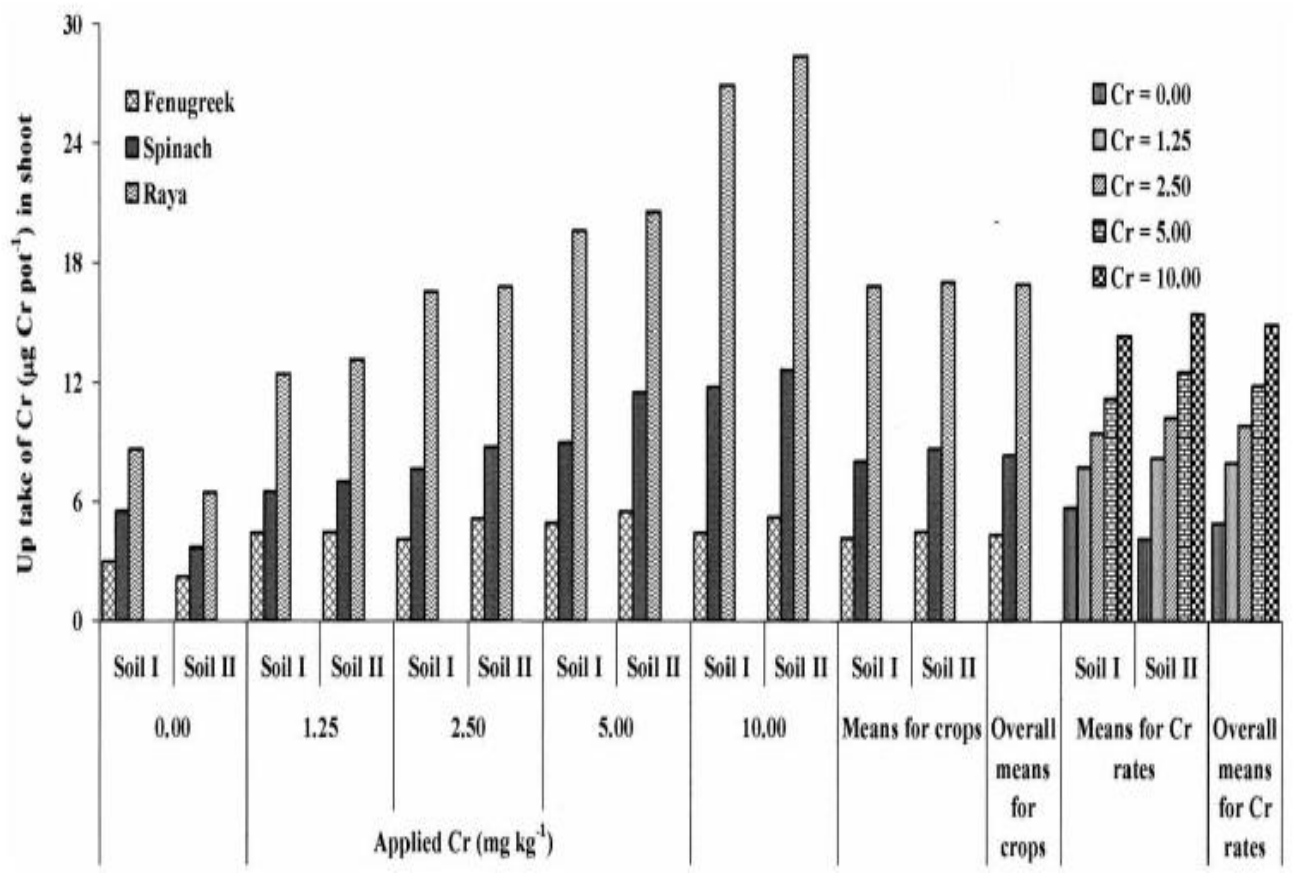

Source (Dheri et al., 2000)

Fig.2 Chromium uptake in the roots of different crops grown in two Cr contaminated soils (soil 1 texture- silty loam and soil 2 - sandy soils)

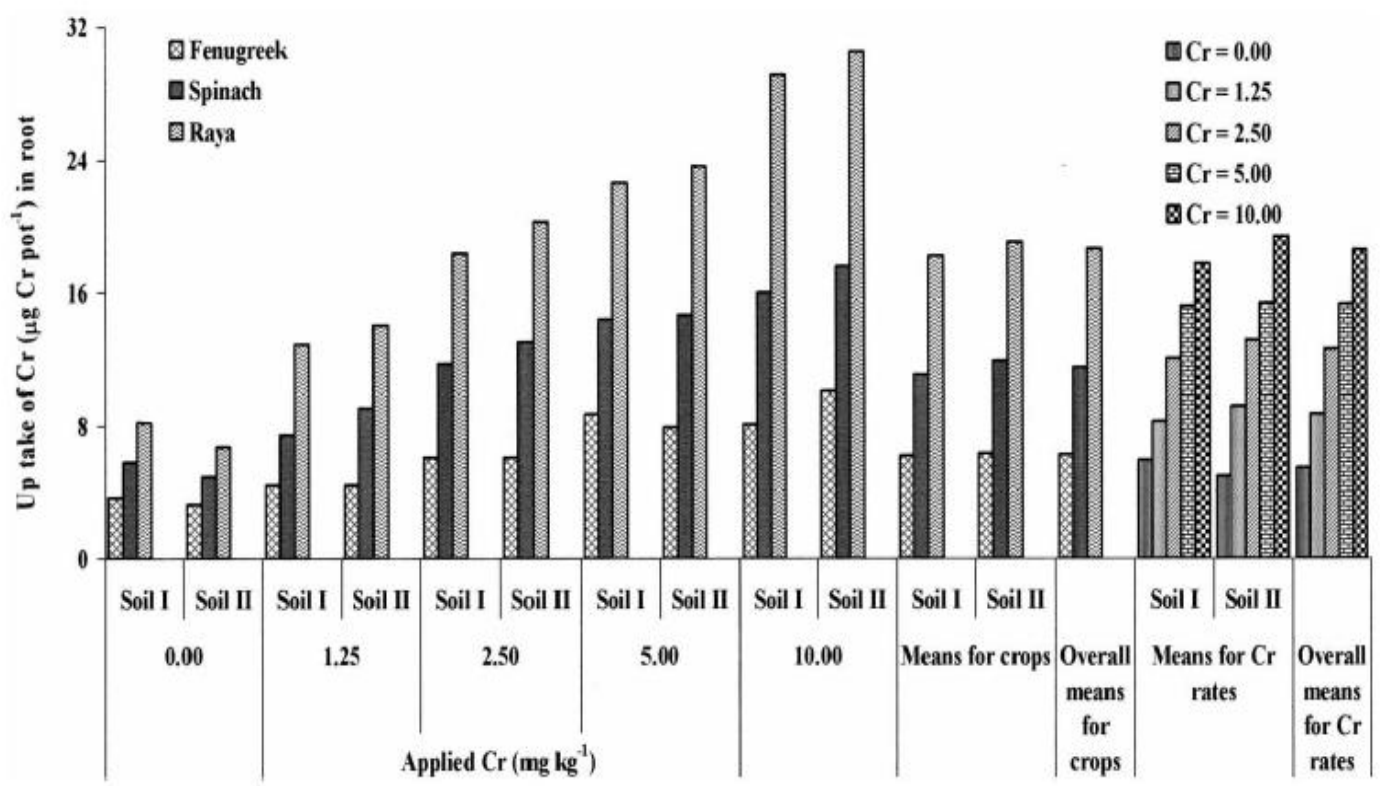

Source (Dehri et al., 2000) 
Fig.3 Average dry biomass (g) grown in chromium treated soils $(n=6)$ on $90^{\text {th }}$ day;

Table 1. Average Dry biomass $(g)$ grown in chromium treated soils $(n=6)$ on $90^{\text {th }}$ day.

\begin{tabular}{cccccccc}
\hline $\begin{array}{c}\text { Total Cr added } \\
\text { in Soil }\left(\mathrm{mg} \mathrm{kg}^{-1}\right)\end{array}$ & $\begin{array}{c}\text { Brassica } \\
\text { campestris }\end{array}$ & $\begin{array}{c}\text { Brassica } \\
\text { juncea }\end{array}$ & $\begin{array}{c}\text { Dhatura } \\
\text { innoxia }\end{array}$ & $\begin{array}{c}\text { Ipomoea } \\
\text { carnea }\end{array}$ & $\begin{array}{c}\text { Phragmytes } \\
\text { karka }\end{array}$ & $\begin{array}{c}\text { Cassia } \\
\text { tora }\end{array}$ & $\begin{array}{c}\text { Lantana } \\
\text { camara }\end{array}$ \\
\hline Control & 3.28 & 3.31 & 12.32 & 19.59 & 11.46 & 12.45 & 5.43 \\
5 & $1.86 * *$ & $2.89 *$ & $8.57 * *$ & $15.01 * *$ & $7.66^{* *}$ & $7.90^{* *}$ & $2.27 * *$ \\
10 & $1.47^{* *}$ & $2.16^{* *}$ & $7.24 * *$ & $11.33^{* *}$ & $5.93 * *$ & $7.30^{* *}$ & $1.93 * *$ \\
20 & $1.36^{* *}$ & $1.17^{* *}$ & $6.49 * *$ & $10.50^{* *}$ & $7.64 * *$ & $7.21 * *$ & $1.76^{* *}$ \\
50 & $\mathrm{NG}$ & $\mathrm{NG}$ & $\mathrm{NG}$ & $\mathrm{NG}$ & $1.51 * *$ & $\mathrm{NG}$ & $1.09 * *$ \\
100 & $\mathrm{NG}$ & $\mathrm{NG}$ & $\mathrm{NG}$ & $\mathrm{NG}$ & $1.06 * *$ & $\mathrm{NG}$ & $\mathrm{NG}$ \\
200 & $\mathrm{NG}$ & $\mathrm{NG}$ & $\mathrm{NG}$ & $\mathrm{NG}$ & $0.78^{* *}$ & $\mathrm{NG}$ & $\mathrm{NG}$
\end{tabular}

Significantly different $*(p \leq 0.05) \& * *(p \leq 0.005)$ in comparison to control plant.

$\mathrm{NG}=$ No Growth observed

$\mathrm{n}=$ number of plants

Source (Gosh and Singh, 2005)

Fig.4 $\mathrm{Cr}$ accumulation (\%) in root and shoot of spinaches olaracea

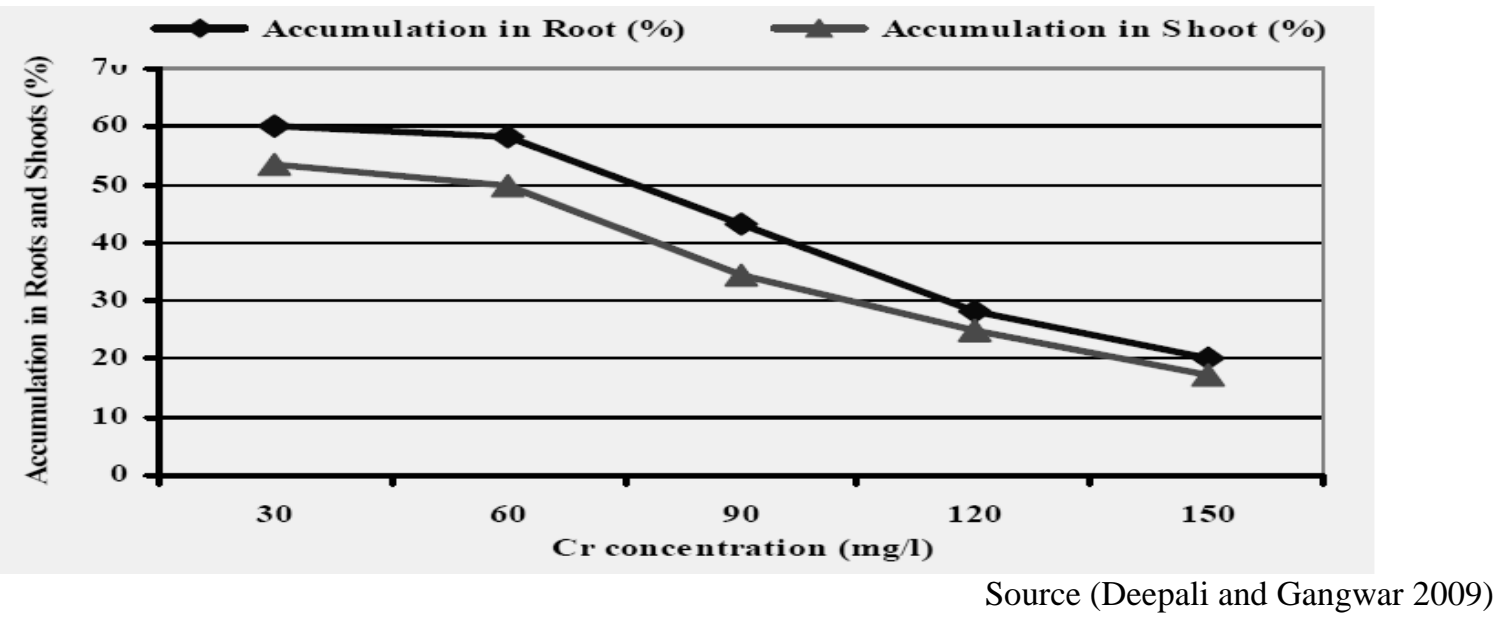

Fig.5 Arsenic (As) concentration in the fronds of Pteris vittata after growing in uncontaminated soil (6 ppm As) and arsenics contaminated soil (400 ppm As)

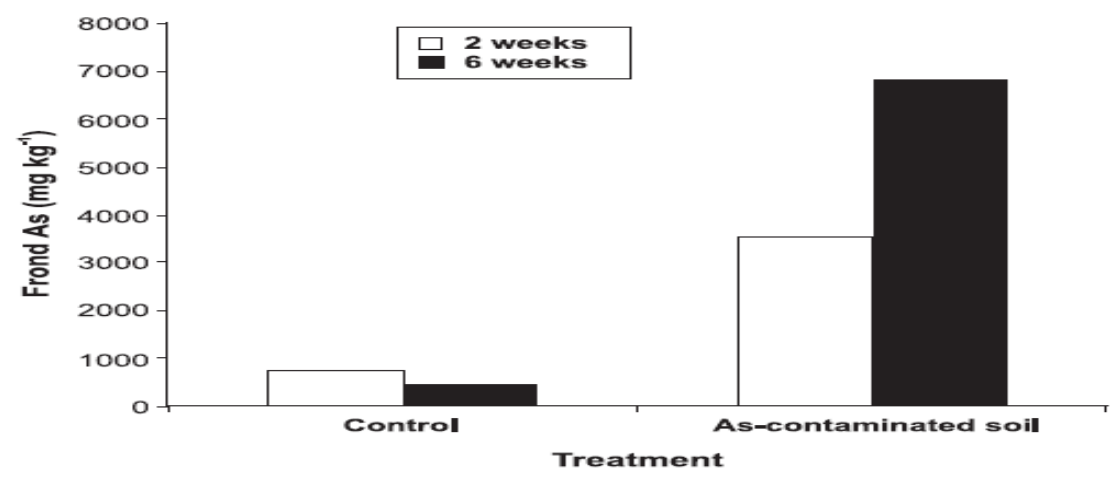

Source (Ma et al., 2001) 
Table.1 Several metal hyperaccumulator species with respective metal accumulated

\begin{tabular}{|l|l|l|l|}
\hline S.no & Plant species & Metal & References \\
\hline $\mathbf{1}$ & Thlaspi caerulescens & $\mathrm{Zn}, \mathrm{Cd}$ & Reeves and Brooks (1983); Baker and Walker (1990) \\
\hline $\mathbf{2}$ & Ipomea alpine & $\mathrm{Cu}$ & Baker and Walker (1990) \\
\hline $\mathbf{3}$ & Sebertia acuminate & $\mathrm{Ni}$ & Jaffre et al., (1976) \\
\hline $\mathbf{4}$ & Haumaniastrum robertii & $\mathrm{Co}$ & Brooks (1977) \\
\hline $\mathbf{5}$ & Astragalus racemosus & $\mathrm{Se}$ & Beath et al., (2002) \\
\hline $\mathbf{6}$ & Arabidopsis thaliana & $\mathrm{Zn}, \mathrm{Cu}, \mathrm{Pb}, \mathrm{Mn}, \mathrm{P}$ & Lasat (2002) \\
\hline $\mathbf{7}$ & Brassica oleracea & $\mathrm{Cd}$ & Salt et al., (1995) \\
\hline $\mathbf{8}$ & Hemidesmus indicus & $\mathrm{Pb}$ & Chandra Sekhar et al., (2005) \\
\hline $\mathbf{9}$ & Pteris vittata & $\mathrm{As}$ & Ma et al., (2001); Zhang et al., (2004); Tu and Ma (2005) \\
\hline $\mathbf{1 0}$ & Helianthus anus & $\mathrm{Cd}, \mathrm{Cr}, \mathrm{Ni}$ & Turgut et al., (2004) \\
\hline
\end{tabular}

Source (Vinita Hooda, 2007)

Table.2 Heavy metal hyperaccumulator $(\mathrm{HMH})$ and non-HMH plant species used in phytoextraction studies included in the meta-analysis and the metals used in phytoextraction.

\begin{tabular}{|c|c|c|c|c|}
\hline Plant species & Family & Common name & Target metal & Reference \\
\hline \multicolumn{5}{|c|}{ Heavy metal hyperaccumulator } \\
\hline Alyssum murale & Brassicaceae & Yellowtuft & $\mathrm{Ni}$ & Abou-Shanab et al., 2006 \\
\hline Alyssum serpyllifolium & Brassicaceae & & $\mathrm{Ni}$ & Ma et al., 2011 \\
\hline Noccaea caerulescens & Brassicaceae & Alpine penny-cress & $\mathrm{Cd}, \mathrm{Zn}$ & $\begin{array}{l}\text { Karimzadeh et al., 2012; Whiting et } \\
\text { al., } 2001\end{array}$ \\
\hline Pteris vittata & Pteridaceae & Chinese brake fern & As & $\begin{array}{l}\text { Lampis et al., 2015; Yang et al., } \\
2012\end{array}$ \\
\hline Sedum alfredii & Crassulaceae & & $\mathrm{Cd}, \mathrm{Zn}$ & Li et al., 2007; Zhang et al., 2012 \\
\hline Sedum plumbizincicola & Crassulaceae & $\mathrm{Cd}, \mathrm{Pb}, \mathrm{Zn}$ & & Liu et al., 2015; Ma et al., 2013 \\
\hline \multicolumn{5}{|c|}{ Non-heavy metal hyperaccumulator } \\
\hline Brassica juncea & Brassicaceae & Indian mustard & $\mathrm{Ni}, \mathrm{Cu}$ & $\begin{array}{l}\text { Rajkumar et al., 2013; Ma et al., } \\
\text { 2011, Ma et al., 2009a; Zaidi et al., } \\
2006\end{array}$ \\
\hline Brassica napus & Brassicaceae & Canola & $\mathrm{Cd}$ & $\begin{array}{l}\text { Dell'Amico et al., 2008; Sheng and } \\
\text { Xia, 2006; Sheng et al., } 2008\end{array}$ \\
\hline Brassica oxyrrhinaa & Brassicaceae & $\begin{array}{l}\text { Smooth-stemmed } \\
\text { turnip }\end{array}$ & $\mathrm{Ni}$ & Ma et al., 2009a \\
\hline Glycine $\max$ & Fabaceae & Soybean & $\mathrm{Cu}$ & Khan and Lee, 2013 \\
\hline Helianthus annuus & Asteraceae & Sunflower & $\mathrm{Cd}, \mathrm{Zn}$ & $\begin{array}{l}\text { Marques et al., 2013; Prapagdee et } \\
\text { al., } 2013\end{array}$ \\
\hline Hordeum vulgare & Poaceae & Barley & $\mathrm{Cd}, \mathrm{Pb}$ & Belimov et al., 2004 \\
\hline Lens culinaris & Fabaceae & Lentil & $\mathrm{Ni}$ & Wani and Khan, 2013 \\
\hline Luffa cylindrica & Cucurbitaceae & Sponge gourd & $\mathrm{Ni}$ & Rajkumar et al., 2013 \\
\hline Lycopersicon esculentum & Solanaceae & Tomato & $\mathrm{Cd}, \mathrm{Pb}$ & He et al., 2009; Sheng et al., 2008 \\
\hline Ricinus communis & Euphorbiaceae & Castor oil plant & $\mathrm{Cu}, \mathrm{Ni}, \mathrm{Zn}$ & Rajkumar and Freitas, 2008 \\
\hline Sinapis alba & Brassicaceae & White mustard & $\mathrm{Cd}, \mathrm{Cu}, \mathrm{Zn}$ & Płociniczak et al., 2013 \\
\hline Solanum nigrum & Solanaceae & Black nightshade & $\mathrm{Cd}$ & Gao et al., 2010 \\
\hline Sorghum halepense & Poaceae & Sorghum & $\mathrm{Cd}, \mathrm{Ni}$ & Rajkumar et al., 2013; Sheng et \\
\hline Thlaspi arvensea & Brassicaceae & Field penny cress & $\mathrm{Zn}$ & Whiting et al., 2001 \\
\hline Vigna radiata & Fabaceae & Mung bean & $\mathrm{Cd}, \mathrm{Ni}, \mathrm{Zn}$ & Rani et al., 2013; Wani et al., 2007 \\
\hline Zea mays & Poaceae & Corn & $\mathrm{Cd}$ & $\begin{array}{l}\text { Malekzadeh et al., 2012; Sheng et } \\
\text { al., } 2008\end{array}$ \\
\hline
\end{tabular}

Source (Jennifer, L.W et al., 2016) 
A fast-growing plant Pteris vittata (Fig. 5) is reported to tolerate arsenic contaminated soils of around 1500 p.p.m and its fronds concentrate the toxic metal to 22,630 p.p.m in just 6 weeks (Ma et al., 2001).

Table 1 and 2 lists some important hyperaccumulators and non-hyper accumulators including the recently discovered ones.

Trees have been suggested as a low-cost, sustainable and ecologically sound solution to the remediation of heavy metal-contaminated land (Dickinson., 2000), Studies of tree establishment on contaminated land have considered a number of different species, e.g. Salix (Willow), Betula (Birch), Populus (Poplar), Alnus (Alder) and Acer (Sycamore).For the purposes of phytoremediation, most attention has been paid to fast-growing species, such as willow. A characteristic of willow, which makes it a very suitable tree for use in phytoremediation, is that it can be frequently harvested by coppicing, yielding as much as 10-15 dry $t$ ha $^{-1}$ year $^{-1}$ (Riddell-Black., 1993). Transgenic (genetically engineered) plants might be another improved way for phytoremediation include Brassica juncea for phytoremediation of heavy metals from soil (Dushenkov et al., 1995), Helianthus anus (Dushenkov et al., 1995) and Chenopodium amaranticolor (Eapen et al., 2003) for rhizofiltration of uranium. It is not yet clear how applicable these transgenic are for environmental cleanup, since no field studies have been reported except one using transgenic Indian mustard plant that overexpresses enzymes involved in sulfate/ selenate reduction (Pilon Smits et al., 1999; Zhu et al., 1999).

Further explorations are needed in the field of Phytoremediation to address technical issues and to find out the geographically suitable plant species for effective phytoremediation.
Accumulation of heavy metals by plants is affected by many factors, variations in plant species, plants growth stage and element characteristics control absorption, accumulation and translocation of metals. Moreover, physiological adaptations also control toxic metal accumulations by sequestering metals in the roots (Guilizzoni 1991). As a result, metal removal by vegetation can be greatly enhanced by the judicious selection of plant species. The knowledge about the abilities of different plant species or tissues to absorb and transport metals under different conditions will provide insight into choosing appropriate plants for phytoremediation of the polluted regions.

\section{References}

Abou-Shanab, R.A., Angle, J.S., Delorme, T.A., Chaney, R.L., Van Berkum, P., Moawad, H., Ghanem, K. and Ghozlan, H.A., 2003. Rhizobacterial effects on nickel extraction from soil and uptake by Alyssum murale. New Phytologist 158: 219-224.

Alloway, B. J. 1995. Soil processes and the behavior of metals. In: Alloway B. J. (Ed), Heavy metals in soils (pp. 38-57). London: Blackie.

Alloway, B.J., Ayres, D.C. 1997. Chemical principles of Environmental Pollution, $2^{\text {nd }}$ Edition, Blackie Academic and Professional, Chapman and Hall, London. 190-242.

Anderson, C. W. N., Brooks, R. R., Chiarucci, A., Lacoste, C. J., Leblanc, M., Robinson, B. H., Simcock, R. and Stewart, R. B. 1999. Phytomining for nickel, thallium, and gold. Journal of Geochemical Exploration, 67: 407-415.

Angle, J. S., Chaney, R. L., Baker, A. J. M, Li, Y., Reeves, R., Volk, V., Roseberg, R., Brewer E., Burke S. and Nelkin J. 2001. Developing commercial phytoextraction technologies: practical considerations. South African Journal of Science, 97: 619-623. 
Aprill, W. and Sims, R. C.1990. Evaluation of the use of prairie grasses for stimulating polycyclic aromatic hydrocarbon treatment in the soil. Chemosphere, 20: 253-265.

Baker, A.J.M. and Walker, P.L.1990. Ecophysiology of metal uptake by tolerant plants. In: Heavy metal tolerance in plants: Evolutionary aspects (Ed: A.J. Shaw). CRC Press, Boca Raton, F.L. pp. 155-177.

Baker, A.J.M., McGrath, S.P., Reeves, R.D.and Smith, J.A.C. 2000. Metal hyperaccumulator plants: A review of the ecology and physiology of a biological resource for phytoremediation of metalpolluted soils. In: Phytoremediation of contaminated soil and water (Eds: $\mathrm{N}$. Terry and G. Banuelos). Boca Raton, Lewis. pp. 85-108.

Baudouin, C., Charveron, M., Tarrouse, R., \& Gall, Y. 2002. Environmental pollutants and skin cancer. Cell Biology and Toxicology, 18: 341-348.

Beath, O.A., Eppsom, H.F. and Gilbert, G.S. 2002. Selenium distribution in and seasonal variation of vegetation type occurring on seleniferous soils. Journal of American Pharmacy Association, 26: 394-405.

Belimov, A.A., Kunakova, A.M., Safronova, V.I., Stepanok, V.V., Yudkin, L.Y., Alekseev, Y.V. and Kozhemyakov, A.P. 2004. Employment of rhizobacteria for the inoculation of barley plants cultivated in soil contaminated with lead and cadmium. Microbiology 73: 99-106.

Boominathan, R., Saha-Chaudhury, N. M., Sahajwalla, V. and Doran, P.M. 2004. Production of nickel bio-ore from hyperaccumlator plant biomass: Applications in phytomining. Biotechnology and Bioengineering, 86: 243-250.

Brooks, R. R., Chambers, M. F., Nicks, L. J. and Robinson B.H. 1998. Phytomining. Trends in Plant Science 3: 359-362.
Brooks, R.R. 1977. Copper and cobalt uptake by Haumaniastrum species. Plant Soil, 48:541-544.

Brooks, R.R. 1988. Plants that hyperaccumulate heavy metals. CAB Intl., Wallingford.

Burken, J. G. and Schnoor, J. L. 1997. Uptake and metabolism of atrazine by poplar trees. Environmental Science and Technology, 31: 1399-1406.

Chandra Sekhar, K., Kamala, C.T., Chary, N.S., Balaram, V. and Garcia, G. 2005. Potential of Hemidesmus indicus for phytoextraction of lead from industrially contaminated soils. Chemosphere, 58(4): 507-514.

Chaney, R. L., Malik, M., Li, Y. M., Brown, S. L., Brewer, E. P., Angle, J. S. and Baker, A. J. M. 1997. Phytoremediation of soil metals. Current Opinion in Biotechnology, 8: 279-284.

Chaney, R.L.,-,Li, Y.M., Brown, L., Homer, F.A. and Malik, M. 2000. Improving metal hyperaccumulator wild plants to develop commercial phytoextraction systems: Approaches and progress. In: Phytoremediation of contaminated soil and water (Eds: N. Terry and G. Bañuelos). Boca Raton, Lewis. pp. 12958.

Cunningham, S. D. and Ow, D. W. 1996. Promises and prospects of phytoremediation. Plant Physiology, 110: 715-719.

Deepali and Gangwar, K. K. 2009.Chromium Uptake Efficiency of Spinacea olaracea from Contaminated Soil. Journal of Applied Science and Environmental Management, 13(4) $71-72$.

Delhaize, A. 1996. A metal accumulator mutant of Arabidopsis thaliana. Plant Physiology, 111(3):849-855.

Dell'Amico, E., Cavalca, L. and Andreoni, V. 2008. Improvement of Brassica napus growth under cadmium stress by cadmium-resistant rhizobacteria. Soil Biology and Biochemistry 40: 74-84.

Dheri, G.S., Brar, M.S and Malhi, S.S. 2007. Comparative Phytoremediation of Chromium- Contaminated Soils by 
Fenugreek, Spinach, and Raya, Communications in Soil Science and Plant Analysis, 38:11-12.

Dickinson, N.M. 2000. Strategies for sustainable woodland on contaminated soils. Chemosphere 41:259-63.

Dunbabin, J.S and Bowmer, K.H. 1992. Potential use of constructed wetlands for treatment of industrial waste waters containing metals. Scientific Total Environment, 111(2.3):151-168.

Dushenkov, S. 2003. Trends in phytoremediation of radionuclides. Plant and Soil, 249: 167-175.

Dushenkov, S., Vasudev, D., Kapulnik, Y., Gleba, D., Fleisher, D., Ting, K. C., et al., 1997a. Removal of uranium from water using terrestrial plants. Environmental Science and Technology, 31(12): 34683474.

Dushenkov, S., Vasudev, D., Kapulnik, Y., Gleba, D., Fleisher, D., Ting, K. C., et al., 1997b. Phytoremediation: A novel approach to an old problem. In D. L. Wise (Ed.), Global environmental biotechnology (pp. 563-572). Amsterdam: Elsevier.

Dushenkov, V., Kumar, P. B. A. N., Motto, H., \& Raskin, I. 1995. Rhizofiltration: The use of plants to remove heavy metals from aqueous streams. Environmental Science and Technology, 29, 1239-1245.

Eapen, S., and D'Souza, S. F. 2005. Prospects of genetic engineering of plants for phytoremediation of toxic metals. Biotechnology Advances, 23, 97-114.

Ensley, B. D. 2000. Rationale for use of phytoremediation. In: I. Raskin and B. D. Ensley (Eds.), Phytoremediation of Toxic Metals. Using Plants to Clean up the Environment, Journal Wiley \& Sons, New York, USA: 3-11.

Gao, Y., et al., 2010. Improvement of phytoextraction and antioxidative defense in Solanum nigrum 1. Under cadmium stress by application of cadmium-resistant strain and citric acid. Journal of Hazardous Materials 181:771-777.
Ghosh, M. and Singh, S. P. 2005. A review of phytoremediation of heavy metals and utilization of its byproducts. Applied Ecology and Environmental Research, 3: 1-18.

Ghosh, M. and Singh, S.P. 2005. Comparative uptake and phytoextraction study of soil induced chromium by accumulator weed species. Applied Ecology and Environmental Research, 3(2): 67-79.

Guilizzoni, P. 1991. The role of heavy metals and toxic materials in the physiological ecology of submersed macrophytes. Aquat Biol, 41(1.3):87-109.

Gurbisu, C and Alkorta, I. 2003. Basic concepts on heavy metal soil bioremediation European Journal Min Process Environmental Protection, 3(1):58-66.

He, L.Y., Chen, Z.J., Ren, G.D., Zhang, Y.F., Qian, M. and Sheng, X.F. 2009. Increased cadmium and lead uptake of a cadmium hyperaccumulator tomato by cadmiumresistant bacteria. Ecotoxicology and Environmental Safety 72:1343-1348.

Hong, M. S., Farmayan, W. F., Dortch, I. J., Chiang, C. Y., McMillan, S. K. and Schnoor, J. L. 2001. Phytoremediation of MTBE from groundwater plume. Environmental Science and Technology, 35: 1231-1239.

Hughes, J. B., Shanks J., Vanderford M., Lauritzen J. and Bhadra, R. 1997. Transformation of TNT by aquatic plants and plant tissue cultures. Envrionmental Science and Technology, 31: 266-71.

Jaffré, T., Brooks, R. R., Lee J. and Reeves, R. D.1976. Sebertia acuminata: a hyperaccumulator of nickel from New Caledonia. Science, 193: 579-580.

Jennifer, L.W., Caixian, Tang., Ashley, E., and Franks. 2016. Microbial associated plant growth and heavy metal accumulation to improve phytoextraction of contaminated soils. Soil Biology \& Biochemistry 103: 131-137.

Karimzadeh, L., Heilmeier, H. and Merkel, B.J., 2012. Effect of microbial siderophore DFO-B on Cd accumulation by Thlaspi caerulescens hyperaccumulator in the 
presence of zeolite. Chemosphere 88: 683-687.

Kay, S. H., Haller, W. T., and Garrard, L. A. 1984. Effect of heavy metals on water hyacinths [Eichhornia crassipes (Mart.) Solms]. Aquatic Toxicology, 5:117-128.

Khan, A.L. and Lee, I.J. 2013. Endophytic Penicillium funiculosum LHL06 secretes gibberellin that reprograms Glycine max L. growth during copper stress. BMC Plant Biology 13.

Knasmuller, S., Gottmann, E., Steinkellner, H., Fomin, A., Pickl, C., Paschke, A., et al., 1998. Detection of genotoxic effects of heavy metal contaminated soils with plant bioassays. Mutation Research, 420: 3748.

Lampis, S., Santi, C., Ciurli, A., Andreolli, M. and Vallini, G., 2015. Promotion of arsenic phytoextraction efficiency in the fern Pteris vittata by the inoculation of As resistant bacteria: a soil bioremediation perspective. Frontiers in Plant Science 6.

Lasat, M.M.2002. Phytoextraction of toxic metals. Journal of Environmental Quality, 31:109-120.

Li, Y.M-, Chaney, R., Brewer, E., Roseberg, R. and Angle, S.J. 2003. Development of a technology for commercial phytoextraction of nickel: Economic and technical considerations. Plant Soil, 249: 107-115.

Liu, W., Wang, Q., Wang, B., Hou, J., Luo, Y., Tang, C. and Franks, A.E., 2015. Plant growth promoting rhizobacteria enhance the growth and $\mathrm{Cd}$ uptake of Sedum plumbizincicola in a Cd-contaminated soil. Journal of Soils and Sediments 1-9.

Ma, L.Q.-, Komar, K.M.-and Tu, C. 2001. A fern that accumulates arsenic. Nature, 409, 579

Ma, Y., Prasad, M.N.V., Rajkumar, M. and Freitas, H., 2011. Plant growth promoting rhizobacteria and endophytes accelerate phytoremediation of metalliferous soils. Biotechnology Advances 29: 248-258.

Ma, Y., Rajkumar, M. and Freitas, H., 2009a. Improvement of plant growth and nickel uptake by nickel resistant-plant-growth promoting bacteria. Journal of Hazardous Materials 166: 1154-1161.

Ma, Y., Rajkumar, M., Luo, Y. and Freitas, H., 2013. Phytoextraction of heavy metal polluted soils using Sedum plumbizincicola inoculated with metal mobilizing Phyllobacterium myrsinacearum RC6b. Chemosphere 93:1386-1392.

Malekzadeh, E., Alikhani, H.A., SavaghebiFiroozabadi, G.R. and Zarei, M. 2012. Bioremediation of cadmiumcontaminated soil through cultivation of maize inoculated with plant growthpromoting rhizobacteria. Bioremediation Journal 16: 204-211.

Marques, A.P.G.C., Moreira, H., Franco, A.R., Rangel, A.O.S.S. and Castro, P.M.L. 2013. Inoculating helianthus annuus (sunflower) grown in zinc and cadmium contaminated soils with plant growth promoting bacteria e effects on phytoremediation strategies. Chemosphere 92: 74-83.

McEldowney, S., Hardman, D. J., \& Waite, S. 1993. Treatment technologies. In $\mathrm{S}$. McEldowney, D. J. Hardman, S. Waite (Eds.), Pollution, ecology and bio treatment (pp. 48-58). Singapore: Longman Singapore Publishers Pvt. Ltd.

Newman, L. A., Strand, S. E., Choe, N., Duffy, J., Ekuan, G. Ruszaj, M., Shurtleff, B. B., Wilmoth, J., Heilman, P. and Gordon, M. P.1997. Uptake and biotransformation of trichloroethylene by hybrid poplars. Environmental Science and Technology, 31: 1062-1067.

Nriagu, J. O. 1979. Global inventory of natural and anthropogenic emissions of trace metals to the atmosphere. Nature, 279: 409-411.

Pilon-Smits, E. A. H. 2005. Phytoremediation. Annual Review of Plant Biology, 56: 1539

Pilon-Smits, E.A.H., de Souza, M.P., Hong-, G., Amini, A.-and R Bravo, R.C.-1999. Selenium volatilization and accumulation 
by twenty aquatic plant species. Journal of Environmental Quality, 28: 1011-1017. Płociniczak, T., Sinkkonen, A., Romantschuk, M., Piotrowska-Seget, Z., 2013. Characterization of Enterobacter intermedius $\mathrm{mh} 8 \mathrm{~b}$ and its use for the enhancement of heavy metals uptake by sinapis alba 1. Applied Soil Ecology 63:17.

Prapagdee, B., Chanprasert, M. and Mongkolsuk, S. 2013. Bioaugmentation with cadmium- resistant plant growthpromoting rhizobacteria to assist cadmium phytoextraction by helianthus annuus. Chemosphere 92: 659-666.

Rajkumar, M., Ma, Y. and Freitas, H. 2013. Improvement of $\mathrm{Ni}$ phytostabilization by inoculation of $\mathrm{Ni}$ resistant Bacillus megaterium sr28c. Journal of Environmental Management 128: 973980.

Rajkumar, M., Ma, Y. and Freitas, H., 2013. Improvement of $\mathrm{Ni}$ phytostabilization by inoculation of $\mathrm{Ni}$ resistant Bacillus megaterium sr28c. Journal of Environmental Management 128: 973980.

Rani, A., Souche, Y. and Goel, R. 2013. Comparative in situ remediation potential of Pseudomonas putida 710A and Commamonas aquatica 710B using plant (Vigna radiata (L.) wilczek) assay. Annals of Microbiology 63: 923-928.

Reeves, R. D., and Brooks, R. R. 1983. Hyperaccumulation of lead and zinc by two metallophytes from a mining area of Central Europe. Environmental Pollution Series A, 31: 277-287.

Reeves, R.D. and Baker, A.J.M. 2000. Phytoremediation of toxic metals. Wiley, New York. pp. 193-229.

Riddell-Black, D. 1993. A review of the potential for the use of trees in the rehabilitation of contaminated land. WRc Report CO 3467. Water Research Centre, Medmenham.

Salt, D.E., Prince, R.C., Pickering, I.J. and Raskin, I. 1995. Mechanisms of cadmium mobility and accumulation in Indian mustard. Plant Physiology, 109:14271433.

Schnoor, J. L., Light, L. A., Mccutcheon, S. C., Wolfe, N. L. and Carreira, L. H. 1995. Phytoremediation of organic and nutrient contaminants. Environmental Science and Technology, 29: 318-323.

Sheng, X., He, L., Wang, Q., Ye, H. and Jiang, C. 2008. Effects of inoculation of biosurfactant- producing bacillus sp. J119 on plant growth and cadmium uptake in a cadmium-amended soil. Journal of Hazardous Materials 155: 17-22.

Sheng, X., He, L., Wang, Q., Ye, H. and Jiang, C., 2008. Effects of inoculation of biosurfactant- producing bacillus sp. J119 on plant growth and cadmium uptake in a cadmium-amended soil. Journal of Hazardous Materials 155: 17-22.

Sheng, X.F. and Xia, J.J. 2006. Improvement of rape (Brassica napus) plant growth and cadmium uptake by cadmium-resistant bacteria. Chemosphere 64: 1036-1042.

Tsao, D. T. 2003. Phytoremediation. Advances in Biochemical Engineering Biotechnology 78. Springer-Verlag, Berlin, Germany. 206 p.

Tu, C. and Ma, L.Q. 2005. Effects of arsenic on concentration and distribution of nutrients in the trends of the arsenic hyperacumlator Pteris vitta $L$. Environmental Pollution., 135(2): 333340.

Turgut, C., Katie Pepe, M. and Cutright, T.J. 2004. The effect of EDTA and citric acid on phytoremediation of $\mathrm{Cd}, \mathrm{Cr}$ and $\mathrm{Ni}$ from soil using Helianthus annuus. Environmental Pollution., 131(1):147154.

Vinita, H. 2007. Phytoremidation of toxic metals from soil and waste water. Journal of environmental biology, 28 (2): 367376.

Wani, P.A. and Khan, M.S. 2013. Nickel detoxification and plant growth promotion by multi metal resistant plant growth promoting rhizobium species rl9. Bulletin of Environmental Contamination and Toxicology 91:117-124. 
Wani, P.A., Khan, M.S. and Zaidi, A. 2007. Effect of metal tolerant plant growth promoting Bradyrhizobium sp. (vigna) on growth, symbiosis, seed yield and metal uptake by greengram plants. Chemosphere 70: 36-45.

Whiting, S.N., De Souza, M.P. and Terry, N., 2001. Rhizosphere bacteria mobilize $\mathrm{Zn}$ for hyperaccumulation by Thlaspi caerulescens. Environmental Science \& Technology 35: 3144-3150.

Wright, D.J and Otte, M.L. 1999. Plant effects on the biogeochemistry of metals beyond the rhizosphere. Bio Environ Proc R Ir Acad 99B(1):3-10.

Yang, Q., Tu, S., Wang, G., Liao, X. and Yan, X., 2012. Effectiveness of applying arsenate reducing bacteria to enhance arsenic removal from polluted soils by Pteris vittata 1. International Journal of Phytoremediation, 14: 89-99.

Yanqun, Z., Yuan, L., Jianjun, C., Haiyan, C., Li, C. and Schvartz, C. 2005. Hyperaccumulation of $\mathrm{Pb}, \mathrm{Zn}$ and $\mathrm{Cd}$ in herbaceous grown on lead-zinc mining area in Yunnan, China. Environmental International, 31(5): 755-762.

Ye, Z.H, Baker, A.J.M., Wong, M.H. and Willis, A.J.1997a.Copper and nickel uptake, accumulation and tolerance in populations of Typha latifolia L. New Phytol, 136(3):469-480.
Ye, Z.H., Baker, A.J.M., Wong, M.H. and Willis, A.J. 1997b. Zinc, lead and cadmium tolerance, uptake and accumulation by the common reed, Phragmites australis (Cav.) Trin. Ex Steudel. Ann. Bot. 80(3):363-370.

Ye, Z.H., Whiting, S.N., Lin, Z.Q., Lytle, C.M., Qian, J.H and Terry, N. 2001.Removal and distribution of iron, manganese, cobalt and nickel within a Pennsylvania constructed wetland treating coal combustion by-product leachate. Journal Environmental Q., 30:1464-1473.

Zaidi, S., Usmani, S., Singh, B.R. and Musarrat, J. 2006. Significance of bacillus subtilis strain sj-101 as a bioinoculant for concurrent plant growth promotion and nickel accumulation in brassica juncea. Chemosphere 64:991-997.

Zhang, W, Cai, Y., Downum, K.R. and Ma, L.Q. 2004. Arsenic complexes in the arsenic hyperaccumulator Pteris vittata, Chinese brake fern. Journal of Chromatography, A. 1043(2): 249-254.

Zhu, Y. L., Zayed, A. M., Quian, J. H., De Souza, M., and Terry, N. 1999. Phytoaccumulation of trace elements by wetland plants: II. Water hyacinth. Journal of Environmental Quality, 28: 339-344.

\section{How to cite this article:}

Mansoor Ali, A.K. Bhat, Tsering Dolkar and Malik, M.A. 2018. Phytoremediation: A Plant Based Technology. Int.J.Curr.Microbiol.App.Sci. 7(03): 766-777. doi: https://doi.org/10.20546/ijcmas.2018.703.090 